\title{
Factors Affecting the Labour Productivity in Construction Projects of Pakistan
}

\author{
Ismail Abdul Rahman ${ }^{1}$, Aftab Hameed Memon ${ }^{2}$, *, Abdul Qadir Memon ${ }^{2}$, Mutahar Ali Shaikh ${ }^{2}$ and Fida Siddiqui ${ }^{3}$ \\ ${ }^{1}$ University Tun Hussein Onn Malaysia, Malaysia \\ ${ }^{2}$ Quaid-e-Awam University of Engineering, Science \& Technology Nawabshah, Pakistan \\ ${ }^{3}$ Mehran University of Engineering \& Technology Jamshoro, Pakistan
}

\begin{abstract}
Construction projects are considered crucial in every developed and developing country from the perspective of economic and social development. Thus, it is mandatory to achieve successful completion of the project. Efficient production is one of the significant criteria in ensuring the success of projects. An efficient production, labour productivity is considered an important aspect. Labour productivity is affected by several factors which are essential to study for productivity improvements. Since in Pakistan, labour productivity is one of the least studied areas within the construction industry. Hence, this paper focused on determining the common factors which have influenced the labour productivity. A survey among the construction practitioners included 33 identified factors from literature. A total of 150 questionnaire forms were distributed, and only 54 completed data forms were received back. These forms were used to analyse statistically using frequency analysis with SPSS software and weighted average (WA) calculation with Microsoft Excel application. The results indicated 1 factor as very often occurring, and other 32 factors were reported as often occurring during construction works while WA value for significance revealed that there are seven factors which have extremely significant while other 26 factors lie in the category of very significant. Those seven dominating factors reported as extremely significant are the misuse of schedule, the increase of labourer age, weather changes, tool and equipment shortages, violation of safety precautions, working seven days per week without taking a holiday and lack of financial motivation system.
\end{abstract}

\section{Introduction}

Construction projects considered as a core contributor to the national economy [1] which provides the necessary infrastructure and fulfils the fundamental need of shelter [2]. Sukumar and Kumar [3] argued that construction is a prime sector which consumes a major portion in the nation's total employment and also contributes to revenue generation of any country. It is reported that in developed countries, construction industry constitutes approximately $10 \%$ of the national income [4]. Besides that, it provides an employment rate of $7 \%$ and $8 \%$ in Europe and the USA, respectively [1 and 5]. Comparatively, in developing countries, the economic contribution of this industry is more imperative than developed countries [6]. Hence, it has made it compulsory to achieve successful completion of the projects. The success of the projects is dependent on several elements among which one of the important elements is labour [7]. Human resources are an uncontrollable and important part in any work [8] which affect significantly on the performance of any project [7]. In South Africa, labour productivity is remarked at the lowest level in for more than 40 years as cited by [2]. This unsatisfactory level of labour productivity is a result of several reasons. Thus, this study is focusing on studying the occurrence and significance of those prevailing reasons. However, the scope of this study was limited to the construction works of Pakistan.

\section{Literature Review}

Productivity is measured concerning outcome achieved against per unit time. It is an established phenomenon that in construction works consumes a significant amount of labour resource. Hence, the performance of labour has a direct effect on the construction cost. Hence, productivity in construction is often measured regarding labour productivity. In construction projects, labour productivity is observed as a complex parameter and is difficult to quantify [7]. Unfortunately, in many countries, the productivity of labour has been declined with time. A serious declination of labour productivity has been observed in Zimbabwe while in Nigeria; labour productivity growth has been unsatisfactory [9]. Thus construction production lies largely on the performance of labour. Performance of labour involved in projects is affected by several factors. Several researchers have put efforts in identifying those factors. A comprehensive list of the factors identified from literature is shown in table 1 below:

\footnotetext{
* Corresponding author: aftabm78@hotmail.com
} 
Table 1. Factors Affecting Labour Productivity

\begin{tabular}{|c|c|c|c|c|c|c|c|c|c|c|c|}
\hline \# & Identified factors & {$[1]$} & {$[2]$} & {$[3]$} & [4] & {$[5]$} & {$[6]$} & {$[7]$} & {$[9]$} & {$[10]$} & [11] \\
\hline 1 & Material shortages & 1 & 1 & 1 & 1 & 1 & 1 & 1 & 1 & 1 & 1 \\
\hline 2 & Tool and equipment shortages & 1 & 1 & 1 & 1 & 1 & 0 & 1 & 1 & 1 & 1 \\
\hline 3 & Weather changes & 1 & 1 & 1 & 1 & 1 & 1 & 0 & 1 & 1 & 1 \\
\hline 4 & Lack of labour experience & 0 & 1 & 1 & 1 & 1 & 1 & 0 & 1 & 1 & 1 \\
\hline 5 & $\begin{array}{l}\text { Drawings and specifications alteration } \\
\text { during execution }\end{array}$ & 1 & 1 & 1 & 1 & 1 & 0 & 0 & 1 & 1 & 1 \\
\hline 6 & Rework / Repairs & 1 & 1 & 1 & 1 & 1 & 0 & 0 & 1 & 1 & 1 \\
\hline 7 & Accidents & 0 & 1 & 1 & 1 & 0 & 0 & 1 & 1 & 1 & 1 \\
\hline 8 & $\begin{array}{l}\text { Misunderstanding between labour and } \\
\text { superintendents }\end{array}$ & 1 & 1 & 0 & 1 & 0 & 0 & 1 & 1 & 0 & 1 \\
\hline 9 & Payment delay & 0 & 1 & 0 & 1 & 0 & 0 & 1 & 1 & 1 & 1 \\
\hline 10 & Labour disloyalty & 1 & 0 & 0 & 1 & 0 & 1 & 0 & 1 & 1 & 1 \\
\hline 11 & Inspection delay & 1 & 0 & 1 & 0 & 0 & 0 & 1 & 1 & 1 & 1 \\
\hline 12 & Working within a confined space & 0 & 1 & 0 & 1 & 1 & 1 & 0 & 1 & 1 & 0 \\
\hline 13 & Lack of financial motivation system & 1 & 0 & 0 & 1 & 1 & 0 & 0 & 1 & 1 & 1 \\
\hline 14 & Working overtime & 0 & 1 & 0 & 1 & 0 & 0 & 1 & 1 & 1 & 1 \\
\hline 15 & Lack of labour supervision & 0 & 0 & 0 & 1 & 0 & 0 & 1 & 1 & 1 & 1 \\
\hline 16 & $\begin{array}{l}\text { Working } 7 \text { days per week without } \\
\text { taking a holiday }\end{array}$ & 0 & 1 & 1 & 0 & 0 & 0 & 0 & 1 & 1 & 1 \\
\hline 17 & Misuse of time schedule & 1 & 0 & 1 & 0 & 0 & 0 & 1 & 1 & 1 & 0 \\
\hline 18 & Supervisors' absenteeism & 1 & 1 & 1 & 0 & 0 & 0 & 0 & 1 & 0 & 1 \\
\hline 19 & Increase of labourer age & 0 & 1 & 0 & 1 & 0 & 0 & 0 & 1 & 1 & 1 \\
\hline 20 & Construction method & 0 & 1 & 0 & 1 & 0 & 0 & 1 & 1 & 1 & 0 \\
\hline 21 & Labour dissatisfaction & 0 & 0 & 1 & 1 & 0 & 0 & 0 & 1 & 1 & 0 \\
\hline 22 & Low quality of raw materials & 0 & 0 & 1 & 0 & 0 & 0 & 0 & 1 & 1 & 1 \\
\hline 23 & Violation of safety precautions & 0 & 0 & 1 & 0 & 0 & 0 & 0 & 1 & 1 & 1 \\
\hline 24 & Interference & 0 & 0 & 0 & 1 & 0 & 0 & 1 & 1 & 1 & 0 \\
\hline 25 & Lack of labour recognition programs & 0 & 1 & 1 & 0 & 0 & 0 & 0 & 1 & 0 & 1 \\
\hline 26 & $\begin{array}{l}\text { Unsuitability of materials storage } \\
\text { location }\end{array}$ & 0 & 0 & 0 & 0 & 0 & 0 & 1 & 1 & 0 & 1 \\
\hline 27 & Lack of competition & 1 & 0 & 0 & 0 & 0 & 0 & 0 & 1 & 0 & 1 \\
\hline 28 & Insufficient lighting & 0 & 0 & 0 & 1 & 0 & 0 & 0 & 1 & 1 & 0 \\
\hline 29 & Inefficiency of equipment & 0 & 1 & 0 & 0 & 0 & 0 & 0 & 1 & 0 & 0 \\
\hline 30 & Misunderstanding among labour & 1 & 0 & 0 & 0 & 0 & 0 & 0 & 1 & 0 & 0 \\
\hline 31 & Increasing number of labours & 0 & 0 & 0 & 0 & 0 & 0 & 0 & 1 & 1 & 0 \\
\hline 32 & High quality of required work & 0 & 0 & 0 & 0 & 0 & 0 & 0 & 1 & 0 & 0 \\
\hline 33 & $\begin{array}{l}\text { Method of employment (using direct } \\
\text { work system) }\end{array}$ & 0 & 0 & 0 & 0 & 0 & 0 & 0 & 1 & 0 & 0 \\
\hline
\end{tabular}

\section{Methodology}

The quantitative approach was adopted in this study to achieve the aim of the project, i.e. uncovering the underlying factors affecting labour productivity. With a total of 33 factors recognized from a review of previous works, a questionnaire was formed and distributed among the stakeholders involved in the construction industry. Questionnaire forms were sent to 150 randomly selected practitioners involved in handling construction works. The practitioners required to mark each factor for Probability of occurrence according to the measurement scale as:

Not occur $=$

Slightly occur $=$

Moderately occur $=$

Often occur $=$

Very often occur $=$ scale $1(0 \%)$ scale $2(1-25 \%)$ scale $3(25-50 \%)$ scale $4(50-75 \%)$ scale $5(75-100 \%)$

At the same time, each factor was also required to mark the level of significance to determine the importance of the factors with the measurement scale as: 

No significant $=$
scale $1(0 \%)$
Slightly significant $=\quad$ scale $2(1-25 \%)$
Moderately significant $=$ scale $3(25-50 \%)$
Very significant $=\quad$ scale $4(50-75 \%)$
Extremely significant $=$ scale $5(75-100 \%)$

Data collected from this survey was analysed by using Average Weight (WA) to assess the level of probability of occurrence and level of severity for each factor. The same method has been adopted by many other researchers to analyse the data gathered from this questionnaire survey. Average Weight (WA) calculated using the following formula:

Where;

$\mathrm{WA}=\frac{1}{4} * \sum \frac{(1 \mathrm{X} 1+2 \mathrm{X} 2+3 \mathrm{X} 3+4 \mathrm{X} 4+5 \mathrm{X} 5)}{\sum(\mathrm{X} 1+\mathrm{X} 2+\mathrm{X} 3+\mathrm{X} 4+\mathrm{X} 5)}$

$\mathrm{X} 1=$ Number of respondents for scale 1

$\mathrm{X} 2=$ Number of respondents for scale 2

$\mathrm{X} 3=$ Number of respondents for scale 3

$\mathrm{X} 4=$ Number of respondents for scale 4

$\mathrm{X} 5=$ Number of respondents for scale 5

\section{Data Analysis and Results}

Data analysis is the process of gathering, elaborating, analysing and transforming the data into useful information. Then based on the properly analysed data, a good approach to conclusion and recommendations of the study can be decided. The main theme of this research is to identify the factors that affect labour productivity in construction. This chapter involves the results of the data obtained through a questionnaire survey.

\subsection{Demographic Analysis}

The demographic analysis involves all the possible detailed information about the respondent's type of organization, years of experience, concerned project cost, and respondents' qualification. Information presented in the form of charts or graphs. Figure 1 represents the type of organization of the respondents.

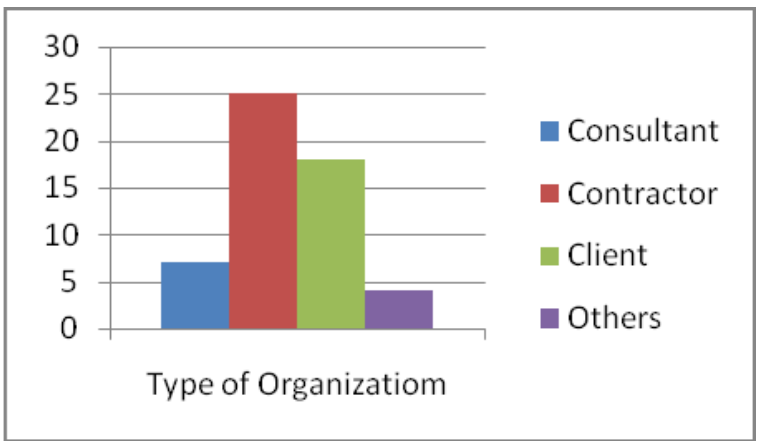

Fig. 1. Respondent's organization

Figure 1 shows $7(12.96 \%)$ of 54 respondents' consultant, 25 (46.29\%) are contractors, 18 (33.33\%) are clients and $4(7.40 \%)$ are others. Respondents work on different type of projects as summarized in figure 2 .

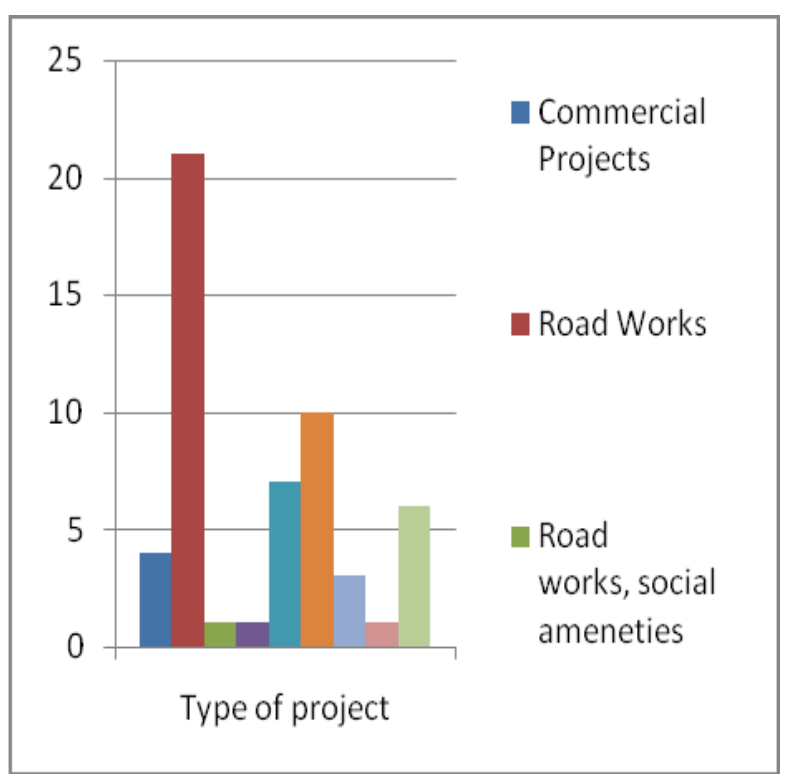

Fig. 2. Types of the project handled by the respondent

Figure 2 shows 4 (7.4\%) respondents work on commercial projects, 21 (38.9\%) work on road projects, $1(1.9 \%)$ work on road and social amenities, 1 $(1.9 \%)$ of the respondents work on road and bridge projects, $7(13 \%)$ work on residential projects, 10 $(18.5 \%)$ respondents work on social amenities projects, $3(5.6 \%)$ work on social amenities and bridges, 1 $(1.9 \%)$ work on bridges, $6(11.1 \%)$ work on other projects. These respondents are involved in different sizes of the projects concerning the cost of the project as given in figure 3 .

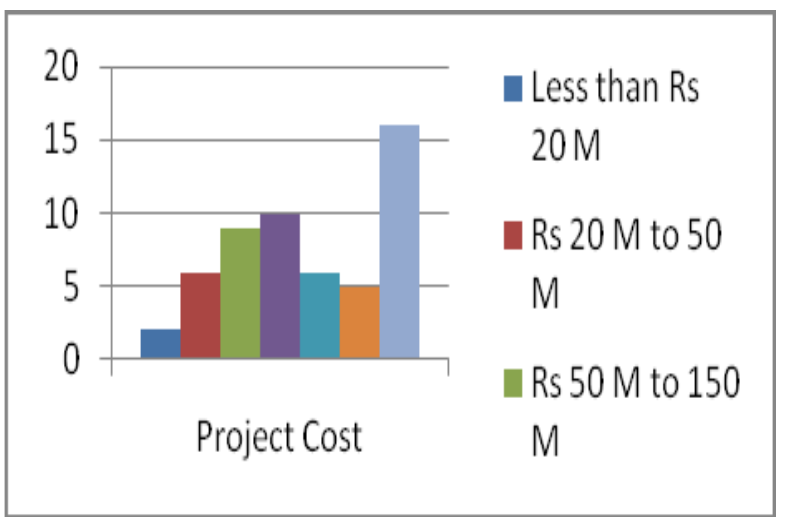

Fig. 3. Size of the projects handled by the respondents

Figure 3 shows that $16(29.6 \%)$ respondents are working on the projects of cost above 3000 million rupees, $5(9.3 \%)$ are working on $1800 \mathrm{M}-3000 \mathrm{M}$ rupees cost project, $6(11.1 \%)$ are working at projects of cost $800 \mathrm{M}-1800 \mathrm{M}$ rupees, $10(18.5 \%)$ are working at cost of $150 \mathrm{M}-180 \mathrm{M}$ rupees, $9(16.7 \%)$ are working at $50 \mathrm{M}-150 \mathrm{M}$ rupees cost of project, $6(11.1 \%)$ are working at $20 \mathrm{M}-50 \mathrm{M}$ and $2(3.7 \%)$ are working less than $20 \mathrm{M}$ out of 54 respondents. The respondents participating in the data collection process are qualified 
and have attained a different level of education as summarized in figure 4 below.

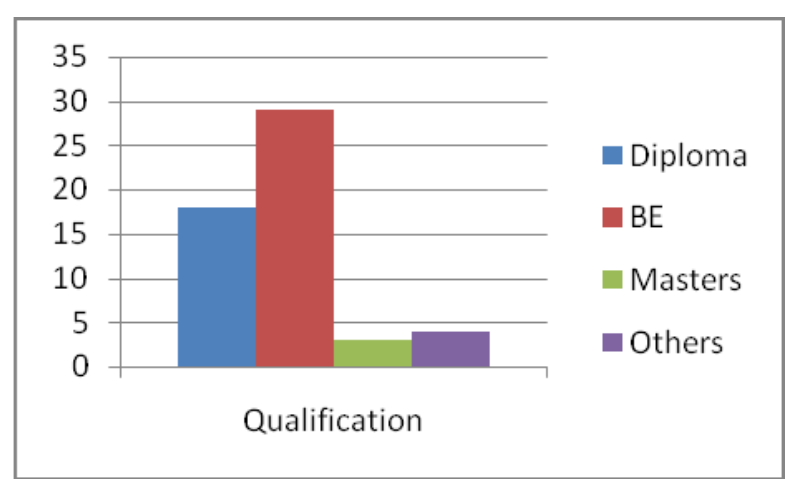

Fig. 4. Respondent's qualification

Fig 4 represents that $18(33.3 \%)$ respondents are diploma holders, 29 (53.7\%) are B.E holder s, 3(5.6\%) are Master's holder, 4 (7.4\%) are others.

\subsection{Occurrence level of factors of labour productivity}

Occurrence level of factors was analysed statistically with Weighted Average (WA) formula. WA value range 0 to 100 and the heightened value shows that the occurrence level is very high. The factors were ranked accordingly, and the results tabulated as in table 2 .

Table 2. Occurrence level of the factors

\begin{tabular}{|l|l|l|l|}
\hline$\#$ & \multicolumn{1}{|c|}{ Factors } & WA & level \\
\hline 1 & Violation of safety precautions & 80.09 & VOO \\
\hline 2 & Weather changes & 75.00 & OO \\
\hline 3 & Payment delay & 73.14 & OO \\
\hline 4 & $\begin{array}{l}\text { Working 7 days per week without } \\
\text { taking a holiday }\end{array}$ & 73.14 & OO \\
\hline 5 & Misuse of time schedule & 72.68 & OO \\
\hline 6 & Increase of labourer age & 71.29 & OO \\
\hline 7 & Insufficient lighting & 70.83 & OO \\
\hline 8 & Tool and equipment shortages & 68.98 & OO \\
\hline 9 & Lack of financial motivation system & 68.98 & OO \\
\hline 10 & $\begin{array}{l}\text { Misunderstanding between labour } \\
\text { and superintendents }\end{array}$ & 68.05 & OO \\
\hline 11 & Rework / Repairs & 67.59 & OO \\
\hline 12 & Working overtime & 67.12 & OO \\
\hline 13 & Accidents & 66.66 & OO \\
\hline 14 & Lack of labour experience & 66.20 & OO \\
\hline 15 & $\begin{array}{l}\text { Drawings and specifications } \\
\text { alteration during execution }\end{array}$ & 66.20 & OO \\
\hline 16 & Inspection delay & 65.74 & OO \\
\hline 17 & Low quality of raw materials & 65.74 & OO \\
\hline 18 & Labour disloyalty & 64.35 & OO \\
\hline 19 & High quality of required work & 64.35 & OO \\
\hline 20 & Increasing number of labours & 64.35 & OO \\
\hline
\end{tabular}

\begin{tabular}{|l|l|l|l|}
\hline 21 & Construction method & 64.35 & OO \\
\hline 22 & Inefficiency of equipment & 63.88 & OO \\
\hline 23 & Interference & 62.96 & OO \\
\hline 24 & Labour dissatisfaction9 & 62.50 & OO \\
\hline 25 & $\begin{array}{l}\text { Method of employment (using direct } \\
\text { work system) }\end{array}$ & 62.50 & OO \\
\hline 26 & Misunderstanding among labour & 62.03 & OO \\
\hline 27 & Lack of competition & 62.03 & OO \\
\hline 28 & Lack of labour recognition programs & 61.11 & OO \\
\hline 29 & Working within a confined space & 60.64 & OO \\
\hline 30 & $\begin{array}{l}\text { Unsuitability of materials storage } \\
\text { location }\end{array}$ & 60.64 & OO \\
\hline 31 & Supervisors' absenteeism & 59.72 & OO \\
\hline 32 & Material shortages & 59.25 & OO \\
\hline 33 & Lack of labour supervision & 56.94 & OO \\
\hline
\end{tabular}

The above table shows that the WA value of probability of occurrence of productivity factors occur in the range of 56 to 80 out of 1 to 5 which express that there is only 1 factor in the category of "Very often occur (VOO)", all other 32 factors fall in the group of "Often occur (OO)"

\subsection{Severity level of Factors}

The level of severity for each factor was also assessed using WA value, and the results presented in table 3 below.

Table 3. Severity level of the factors

\begin{tabular}{|c|c|c|c|}
\hline \# & Factors & WA & level \\
\hline 1 & Misuse of time schedule & 79.62 & ES \\
\hline 2 & Increase of labourer age & 77.77 & ES \\
\hline 3 & Weather changes & 77.31 & ES \\
\hline 4 & Tool and equipment shortages & 76.38 & ES \\
\hline 5 & Violation of safety precautions & 76.38 & ES \\
\hline 6 & $\begin{array}{l}\text { Working } 7 \text { days per week without } \\
\text { taking a holiday }\end{array}$ & 75.92 & ES \\
\hline 7 & Lack of financial motivation system & 75.46 & ES \\
\hline 8 & Accidents & 73.14 & VS \\
\hline 9 & Insufficient lighting & 73.14 & $\mathrm{VS}$ \\
\hline 10 & Inspection delay & 72.68 & VS \\
\hline 11 & Labour dissatisfaction & 72.68 & $\mathrm{VS}$ \\
\hline 12 & Labour disloyalty & 72.22 & VS \\
\hline 13 & High quality of required work & 72.22 & VS \\
\hline 14 & Construction method & 72.22 & VS \\
\hline 15 & Lack of labour experience & 71.75 & VS \\
\hline 16 & Rework / Repairs & 71.29 & VS \\
\hline 17 & $\begin{array}{l}\text { Unsuitability of materials storage } \\
\text { location }\end{array}$ & 70.83 & $\mathrm{VS}$ \\
\hline 18 & Interference & 69.90 & VS \\
\hline 19 & Working overtime & 68.05 & VS \\
\hline
\end{tabular}




\begin{tabular}{|c|l|l|l|}
\hline 20 & Payment delay & 67.59 & VS \\
\hline 21 & $\begin{array}{l}\text { Misunderstanding between labour } \\
\text { and superintendents }\end{array}$ & 67.12 & VS \\
\hline 22 & Lack of labour recognition programs & 67.12 & VS \\
\hline 23 & Lack of labour supervision & 66.66 & VS \\
\hline 24 & Lack of competition & 66.66 & VS \\
\hline 25 & Material shortages & 65.27 & VS \\
\hline 26 & $\begin{array}{l}\text { Drawings and specifications } \\
\text { alteration during execution }\end{array}$ & 65.27 & VS \\
\hline 27 & Inefficiency of equipment & 65.27 & VS \\
\hline 28 & Working within a confined space & 65.27 & VS \\
\hline 29 & Supervisors' absenteeism & 64.35 & VS \\
\hline 30 & $\begin{array}{l}\text { Method of employment (using direct } \\
\text { work system) }\end{array}$ & 64.35 & VS \\
\hline 31 & Misunderstanding among labour & 63.88 & VS \\
\hline 32 & Increasing number of labours & 60.18 & VS \\
\hline 33 & Low quality of raw materials & 56.48 & VS \\
\hline
\end{tabular}

Table 2 showed it is clear that based on WA value of the factors, 7 of 33 factors marked as "Extremely significant (ES)" while other 26 factors marked as "Very significant (VS)" factors.

\section{Conclusion}

This study was carried out quantitatively aiming to uncover the factors of labour productivity in construction projects of Pakistan. It involved survey with a questionnaire consisting of 33 factors in getting the perception of the stakeholders regarding occurrence and severity level of the factors with a 5-point measurement scale. Gathered 54 questionnaire forms were analysed with frequency analysis and weighted average (WA). The results indicated 1 factor as very often occurring and other 32 factors while from perspective of severity level 7 factors reported as extremely significant are extremely significant are misuse of time schedule, increase of labourer age, weather changes, tool and equipment shortages, violation of safety precautions, working 7 days per week without taking a holiday and lack of financial motivation system

The researchers are very much thankful to Universiti Tun Hussein Onn Malaysia for supporting this research work primarily regarding financial support to meet the registration fees of the conference.

\section{References}

1. A. Soekiman, K.S. Pribadi, B.W. Soemardi, R.D. Wirahadikusumah. Factors Relating to Labor Productivity Affecting the Project Schedule Performance in Indonesia. Procedia Engineering 14 (2011) 865-873
2. B. Chigara and T. Moyo. Factors Affecting Labor Productivity on Building Projects in Zimbabwe. International Journal of Architecture, Engineering and Construction 3, 1 (2014) 57-65

3. D. Sukumar and V.R. Kumar. A Study of Various Factors Affecting Labour Productivity and Methods to Improve It. International Journal of Scientific \& Engineering Research 7, 4 (2016)

4. H.M. Alinaitwe, J.A. Mwakali and B. Hansson. Factors affecting the productivity of building craftsmen - studies of Uganda, Journal of Civil Engineering and Management 13, 3 (2007) 169176

5. M.R. Abdul Kadir, W.P. Lee, M.S. Jaafar, S.M. Sapuan and A.A.A. Ali. Factors affecting construction labour productivity for Malaysian residential projects. Structural Survey 23, 1 (2005) 42-54

6. N.Z. Muhammad, A. Sani, A. Muhammad, S. Balubaid, E.E. Ituma, and J.H. Suleiman. Evaluation of factors affecting labour productivity in construction industry: a case study. Jurnal Teknologi 77, 12 (2015) 87-91

7. B.G. Hicksona and L.A. Ellis. Factors affecting Construction Labour Productivity in Trinidad and Tobago. The Journal of the Association of Professional Engineers of Trinidad and Tobago 42, 1 (2014) 4-11

8. A. Kazaz and S. Ulubeyli. Drivers of Productivity Among Construction Workers: A Study in a Developing Country, Building and Environment 42, 5 (2007) 2132-2140.

9. A. Enshassi, S. Mohamed, Z.A. Mustafa, and P.E. Mayer. Factors affecting labour productivity in building projects in the Gaza strip, Journal of Civil Engineering and Management, 13, 4 (2007) 245254

10. B. H. Shah. Factors Affecting Construction Labor Productivity on Building Projects in Pakistan. Master thesis, National University of Sciences \& Technology

11. T.G.S.R. Gopal and K. Murali. Analysis of factors affecting labour productivity in construction. International Journal of Recent Scientific Research 7, 6 (2016) 1744-11747 